\title{
Geotechnical properties of sewage sludge solidified with Sulphoaluminate cement
}

\author{
Xihui Fan $^{1 *}$, Haoqing Xu², Shengwei Wang ${ }^{3}$, Shi Shu ${ }^{1}$, Naixi $\operatorname{Lin}^{4}$, Yongjin Qian ${ }^{1}$ \\ ${ }^{1}$ Geotechnical Research Institute, Hohai University, 210098 Nanjing, China \\ ${ }^{2}$ School of Architecture and Civil Engineering, Jiangsu University of Science and Technology, \\ 212003, Zhejiang, China \\ ${ }^{3}$ Institute of Geotechnical Engineering, Yangzhou University, 225127 Yangzhou, China \\ ${ }^{4}$ College of Environment, Hohai University, 210098 Nanjing, China
}

\begin{abstract}
The geotechnical properties of sewage sludge solidified with sulphoaluminate cement are presented. The sludge has a high water content and organic matter which is not easy to disposal. After Solidification/Stabilization $(\mathrm{S} / \mathrm{S})$, landfill disposal of sewage sludge is widely adopted in China. However, there is little research focused on the geotechnical properties of sewage sludge after $\mathrm{S} / \mathrm{S}$ treatment and the impact on the landfill site is also difficult to be evaluated. To solve this problem, this paper is aimed to evaluate the basic mechanics properties of solidified materials by means of Atterberg limit, triaxial test, consolidation test and permeability test. The result showed that the strength and the hydraulic conductivity of the modified sludge was close to that of the high organic soil. By adding suitable additives, modified sludge could not only satisfy the requirement of being landfilled but also be utilized as a construction material.
\end{abstract}

\section{INTRODUCTION}

Civil sludge is the by-product during the process of urban sewage treatment. With urban development, production of urban sewage is increasing in the past decades. As by-product of sewage treatment, the production of sludge is also on the rise. According to The 12th Five-Year Plan for Town Sewage Treatment and Recycling Facilities Construction in China, waste water treatment capacity of Chinese facilities had reached 125 million cubic meters/day till the end of 2010. Suppose that treatment rate of domestic sewage has reached 77.5\%; during "the 12th Five-Year Plan", the newly built sludge treatment scale should reach 5.18 million tons (dry sludge) / year.

To reclamation the organic soil with high moisture content effectively, many methods adopted to disposal the sewage sludge, such as land application, surface disposal, landfilling, incineration and so on. However, due to the germs and heavy metals contained in the sludge, land application is limited. And the incineration and landfilling will put a

*Corresponding author: fanxihui@gmail.com 
burden on the environment. Using the treated sewage sludge as landfill cover, can not only save the soil resource for the landfill but reclaim the sludge.

To meet the requirement for the sludge landfill, some methods were put forward to modify the sewage sludge. Lim et al. used the modifier such as lime, loess, and fly ash to stabilize the sludge as construction materials [1]. Koenig et al. studied the dewatered sludge and got a valuable basis for understanding the sludge characteristics and behavior to landfill design [2]. And the sludge might meet the increasing demand of landfill cover materials. Inga Herrmann et al. found that the fly ash-sewage sludge could meet the limit permeability value for use in landfill cover liners [3]. Kim et al. proposed a solidification process of the hydrated sludge, slag and quick lime [4].

Many scholars put forward solution to solidifying of the sludge by reducing the moisture content and adding large amount of admixture. But the sludge with high water content is hard to be dewatered, which needs much energy and time. The aims of this study are to dispose the raw sludge with early-strength additive and identify the possibility of using the modified sludge as landfill cover material.

\section{METHODS AND MATERIALS}

\subsection{Sewage sludge}

Sludge in this experiment were obtained from Nanjing Jiangxinzhou Sewage Treatment Plant in China. Basic properties of sewage sludge used in this experiment are given in Table 1 . The moisture content of sludge is basically close to the liquid limit and the bulk density was as low as $1.164 \mathrm{~g} / \mathrm{cm}^{3}$.

In order to simulate the practical construction condition, the test sludge won't be adequately dewatered; instead, it is directly mixed with solidifying agent. Water content and organic content in the sludge are measured follow the ASTM D2904-00[5]. Grain size analysis test of sludge is conducted by laser particle analyzer (Mastersizer2000) as shown in Figure. 1. The sludge particle is quite fine, similar to clay, of which $d(0.5)=60.655 \mu \mathrm{m}$ and $\mathrm{d}(0.9)=246.065 \mu \mathrm{m}$.

Table 1. some properties of sludge from wastewater plant

\begin{tabular}{|c|c|c|c|c|c|c|c|}
\hline Properties & $\begin{array}{c}\text { Liquid } \\
\text { Limit }\end{array}$ & $\begin{array}{c}\text { Plastic } \\
\text { Limit }\end{array}$ & $\begin{array}{c}\text { Plastic } \\
\text { index }\end{array}$ & $\begin{array}{c}\text { Organic } \\
\text { content }\end{array}$ & $\begin{array}{c}\text { Water } \\
\text { content }\end{array}$ & $\begin{array}{c}\text { Bulk } \\
\text { density }\end{array}$ & $\mathrm{pH}$ \\
\hline Content & $284.6 \%$ & $53.8 \%$ & $230.8 \%$ & $28.2 \%$ & $253.8 \%$ & $1.164 \%$ & 7.59 \\
\hline
\end{tabular}

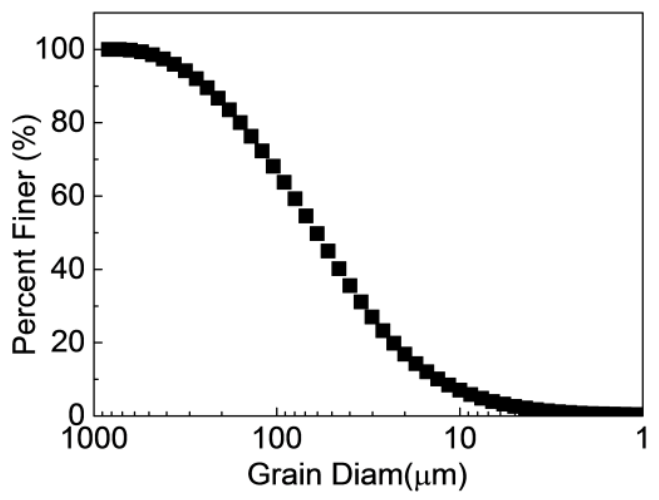

Fig. 1. Sludge grain size distribution 


\subsection{Sulphoaluminate cement}

Sulphoaluminate cement (hereafter referred to as $\mathrm{S}$ for short in the figures), which adopted as additive to the modified sludge, is a new type of cement that can be hardened and strengthened quickly. It mainly composed of anhydrous calcium sulphoaluminate and dicalcium silicate. Cement grade of the Sulphoaluminate cement in this experiment was 425 , which means that strength of the cement can reach $42.5 \mathrm{MPa}$ after 3 days. Table 2 presents the chemical composition of sulphoaluminate cement clinker

Table 2. Chemical composition of sulphoaluminate cement clinker

\begin{tabular}{|c|l|l|l|l|l|l|l|}
\hline Parameters & $\begin{array}{l}\mathrm{SiO} 2 \\
/ \%\end{array}$ & $\begin{array}{l}\mathrm{Al} 2 \mathrm{O} 3 \\
/ \%\end{array}$ & $\begin{array}{l}\mathrm{Fe} 2 \mathrm{O} 3 \\
/ \%\end{array}$ & $\begin{array}{l}\mathrm{CaO} \\
/ \%\end{array}$ & $\begin{array}{l}\mathrm{MgO} \\
/ \%\end{array}$ & $\begin{array}{l}\mathrm{SO} 3 \\
/ \%\end{array}$ & $\begin{array}{l}\text { LOI } \\
/ \%\end{array}$ \\
\hline Content & 284.6 & 53.8 & 230.8 & 28.2 & 253.8 & 1.164 & 7.59 \\
\hline
\end{tabular}

\subsection{Geotechnical experiment}

Mechanical agitation was carried out for additive $\mathrm{S}$ and raw sludge in different proportions. After being mixed uniformly, the mixed sludge was cured at $90 \%$ relative humidity with the different temperature of $20^{\circ} \mathrm{C}$ and $40^{\circ} \mathrm{C}$. Unconfined test, triaxial test, permeability test, and compression test were conducted for modified sludge of different ages.

The force condition of modified sludge was different under the overburden pressure and backfill rolling-compacting condition, so the unconfined compressive strength analysis and triaxial test were conducted for it, both of which follow the standards of the Ministry of Construction of the People's Republic of China [6].

Home-made flexible wall permeameter was adopted in permeability test, as shown in Figure. 2. The diameter of the specimen was $70 \mathrm{~mm}$ and the height was $40 \mathrm{~mm}$. Because the consolidation pressure of the modified sludge was changing during the landfilling process, three different consolidation pressures, $30 / 60 / 90 \mathrm{kPa}$, were put on prior to the permeability test.

Modified automatic consolidation instrument is adopted for compression test. The dimension of sample was $30 \mathrm{~cm}^{2}$, and the height was $40 \mathrm{~mm}$. And the consolidation pressure ranged from $12.5 \mathrm{kPa}$ to $200 \mathrm{kPa}$.



Fig. 2. Flexible wall permeameter 


\section{RESULTS}

\subsection{Atterberg limit}

The Atterberg limit was used to evaluate the physical change of the modification process of sludge. The relationship between various amount of sulphoaluminate cement additions and liquid limit (LL), plastic limit(PL), plastic index(PI) of the specimens were shown in Figure 3. The liquid limit and plastic index of modified sludge reduce with the admixture amount, while plastic limit of modified sludge rised greatly. Water content of the original sludge is close to liquid limit and the liquidity index reached 0.87. And after adding the sulphoaluminate cement, liquidity index of sludge decreases effectively.



Fig. 3. The Atterberg limit of the modified sludge

\subsection{Unconfined compression strength (UCS) test and triaxial test}

To evaluate the strength characteristics of the modified sludge backfill rollingcompaction, the unconfined compressive strength with various admixture amount at different curing age were displayed in Figure 4. UCS of modified sludge with different proportions increases rapidly during the first 24 hours. However, from the 1 st day to the 40th day, strength of modified sludge does not change obviously. The amount of the addition of sulphoaluminate cement had a significant influence on the strength of the sludge. The UCS of the modified sludge with $15 \%$ sulphoaluminate cement increase obviously comparing with the $10 \%$ addition, and maintain it above $100 \mathrm{kPa}$ 。 And the modified sludge with $5 \%$ or $10 \%$ addition only had the the strength below $50 \mathrm{kPa}$.

In order to study the mechanical characteristics of modified sludge whose proportion is larger than $15 \%$, modified sludge with $15 \%$ and $20 \%$ admixture were cured under $20^{\circ} \mathrm{C}$ and $40^{\circ} \mathrm{C}$ for 1 day, 7 days and 30 days and evaluated by triaxial test. The changes of cohesion force(c) and internal friction angle $(\varphi)$ were shown in the Figure 5. Cohesion and internal friction angle of modified sludge are relatively stable within 30 days. With the increase of the admixture amount, the cohesion and internal friction angle increased obviously. And the c, $\varphi$ of the modified sludge with the curing temperature of $40^{\circ} \mathrm{C}$ were lower than that of $20^{\circ} \mathrm{C}$. 




Fig. 4. Unconfined compression strength of the modified sludge

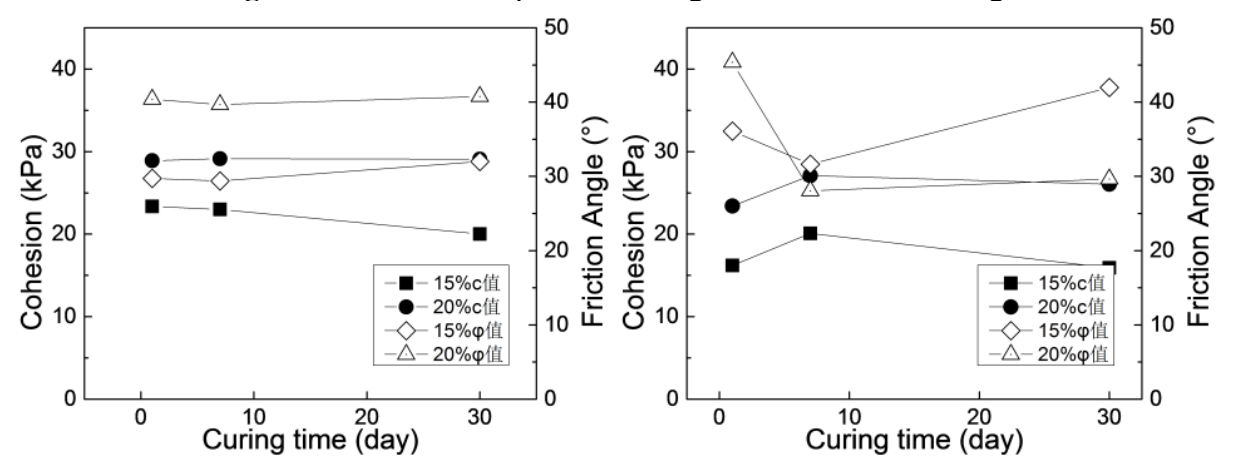

Fig. 5. The cohesion and friction of the modified sludge with the curing time

\subsection{Compressibility of the modified sludge}

The compressibility of modified sludge with curing time of 1 and 30 days were compared as shown in Figure 6. With the increase of modified material content, compressibility of modified sludge reduces obviously. The compression coefficient of the modified sludge with $20 \%$ admixture added was only $1 / 5 \sim 1 / 3$ of that with $10 \%$ admixture. The curing condition and age had less impact when the modified sludge had $20 \%$ admixture. And the compressibility was about $1.8 \mathrm{MPa}^{-1}$.



Fig. 6. The cohesion and friction of the modified sludge with the curing time 


\subsection{Permeability of the mixed sludge}

As for solidifying sludge or modified sludge as daily or intermediate cover in landfill, permeability of the material was very important. Figure 7 shows the relationship between hydraulic conductivity and the consolidation pressure with different admixture content. The permeability of the modified sludge with $10 \%$ admixture is reduced by about two orders of magnitude when the consolidation pressure increases from $30 \mathrm{kPa}$ to $90 \mathrm{kPa}$. The additive amount influences the change of the permeability. The permeability of modified sludge with less additive is more sensitive to the consolidation pressure. The decrease of the permeability of the sludge with $20 \%$ mixture is much less than that with $10 \%$ additive from the consolidation of $30 \mathrm{kPa}$ to $90 \mathrm{kPa}$.



Fig. 7. The relationship between the permeability and the consolidation pressure(curing time=30days)

\section{DISUSSION}

\subsection{Atterberg limit}

With the addition of the sulphoaluminate cement, the plastic limit, strength, compressibility, permeability of the sludge with $253 \%$ water content changed a lot. The liquidity index of the raw sludge wad 0.87 , and the plastic limit was as high as 230 . The plastic index decreased to 58 after the addition of $20 \%$ admixture. Plastic index had influence on the compressibility, cohesion, internal friction angle and so on in terms of the mechanics properties. The plastic limit (or liquid limit) had significant influence on the soil compaction [6]. And there was negative linear correlation between plastic limit and maximum dry unit weight[7].It could be much easier for the mechanical execution for the modified sludge with $15 \%$ or $20 \%$ additive.

According to the sludge landfill requirement, the internal strength is no less than 50 $\mathrm{kPa}$. The sludge behaved like the liquid, and it could not be dumped in the landfill, unless in the sludge-only landfills (known as monofills). The modified sludge with 15\% admixture and 1 day curing time could maintain the UCS above $100 \mathrm{kPa}$, which satisfy the strength requirement of the sludge landfills[8].

The permeability was an important parameter for the daily or intermediate landfill cover material, which was less than $10^{-7} \mathrm{~cm} / \mathrm{s}$ for the purpose of reducing the infiltration of rainfall[9]. And it needs to be free draining so that perched leachate does not become a 
problem[10].Due to the high compressibility of the modified sludge, the hydraulic conductivity would decrease for the on-going overlying pressure. So it was not easy draining under high overlying pressure, which needed to be considered in the future.

\section{CONCLUSIONS}

In this paper, the sulphoaluminate cement was utilized as solidifying material to improve the mechanics behavior of the organic soil to satisfy the requirement of the landfill cover material. The conclusions are summarized as follows:

(1) The addition of the sulphoaluminate cement reduced the plastic index and make it easy for the backfill rolling-compacting.

(2) The strength of the modified sludge increased rapidly after the additive mixture. Properties of modified sludge would remain stable after 24 hours and steady unconfined compression strength can be maintained. When the adding amount of modified materials is above $15 \%$, the strength can support machines that work on it. The addition of sulphoaluminate cement could obviously increase cohesion and internal friction angle of modified sludge.

(3) The modified sludge was high-compressible- soil, and the overlying pressure would decrease the hydraulic conductivity. The hydraulic conductivity of the modified sludge was less than $10^{-7} \mathrm{~cm} / \mathrm{s}$ under $90 \mathrm{kPa}$ consolidation pressure, which was required for the landfill cover material.

(4) The mechanics properties of the modified sludge improved with the additive. The strength meet the requirement for the material used as daily or intermediate landfill cover. The modified sludge could be an alternative for the landfill cover material.

\section{ACKNOWLEDGEMENTS}

This research was funded by the Fundamental Research Funds for the Central Universities (2015B35614).

\section{References}

1. S. Lim, W. Jeon, J. Lee, K. Lee, N. Kim, Engineering properties of water/wastewatertreatment sludge modified by hydrated lime, fly ash and loess. Water Research, 36, 4177-4184 (2002)

2. A. Koenig, J. Kay, I. Wan, Physical properties of dewatered wastewater sludge for landfilling. Water Science and Technology, 34, 533-540 (1996)

3. I. Herrmann, M. Svensson, H. Ecke, J. Kumpiene, C. Maurice, L. Andreas, A. Lagerkvist. Hydraulic conductivity of fly ash-sewage sludge mixes for use in landfill cover liners. Water Research, 43, 3541-3547(2009)

4. E. Kim, J. Cho, S. Yim. Digested sewage sludge solidification by converter slag for landfill cover. Chemosphere, 59, 387-395(2005)

5. American Society for Testing and Materials, ASTM. Standard Test Methods for Moisture, Ash, and Organic Matter of Peat and Other Organic Soils: ASTM International (2007)

6. B. Ball, D. Campbell, E. Hunter. Soil compactibility in relation to physical and organic properties at 156 sites in UK. Soil and Tillage Research, 57, 83-91(2000) 
7. A. Sridharan \& HB, Nagaraj, Plastic limit and compaction characteristics of finegrained soils. Proceedings of the ICE-Ground Improvement, 9, 17-22(2005)

8. Y. Qu, W. Zhu, L. Li, Z. Xu, Research on the Feasibility of Engineering Application for Solidified Sludge Landfill. Journal of Environmental Science and Engineering, 4: 47(2010)

9. X. Qian, RM. Koerner, DH. Gray. Geotechnical Aspects of Landfill Design and Construction. Prentice Hall PTR(2002)

10. Environmental Protection Agency, Lreland. Guidace Note on MSW Landfill Daily and Intermediate Cover (2011) 